\title{
Women's Representations in Novel Negeri Perempuan by Wisran Hadi and Novel Kenanga by Oka Rusmini: A Study of Literature Sociology
}

\author{
Abdul Mu'is 1,* \\ ${ }^{1}$ Indonesian Language Department, Universitas Negeri Padang, Padang, West Sumatra, Indonesia \\ *Corresponding author. Email: dulmuis29@gmail.com
}

\begin{abstract}
Novel is a literary work that is long and the heart of a writer is conveyed through writing or works. The novel Negeri Perempuan dan Kenanga are two works by writers of different genders and different regions. This study will discuss and analyze narrative words or sentences, dialogues that represent Minang Kabau women and Balinese women, using a sociological study of literature. The aim of the research is toDescribe how the representation of women in the novel Negeri Perempuan by Wisran Hadi. Describe how the representation of women in the novel Kenanga by Oka Rusmini. Describe how the different depictions of women's representation in the novel Negeri Perempuan by Wisran Hadi and Kenanga by Oka Rusmini.This research uses descriptive analysis method. Data collection techniques in this study are reading, taking notes. Data analysis techniques are carried out by identifying, analyzing, concluding, and writing research reports. The results of the study indicate that the two novels represent the conflicts of women in the family and women in society who have rights and obligations according to their customs and culture, race or caste.
\end{abstract}

Keywords: Representation of Women, Novel, Country of Women, Kenaga

\section{INTRODUCTION}

Literature is an art that is presented in the form of a work that has meaning or content about humans and humanity [1]. Regarding this, Rusyana [2] argues that literature is a human work in expressing, the appreciation of human life to in a work using beautiful language, language that has an emotional effect on the reader.

The sudden strong outburst of feelings is conveyed by the author in a literary work that describes emotional and various problems. The problems experienced by women, especially in their daily lives and in accordance with the provisions that apply in their respective regions. An author Those who are in the community are more free to describe the social clearly and clearly in their work.

A person's literary work is a work of reality added to the author's imagination. In this case, many aspects of women who get such intimidation or problems raised in the work according to their respective regions such as Wisran Hadi's work Negeri Perempuan is a novel that represents women from different backgrounds. Minang area or West Sumatra which is thick with customs and customs, and how they glorify women so that they are called Bundo Kanduang. And bundo biological is also the person who keeps the customs and protects the community in their horror. Even though in essence women are still under men in the sense of the word nature, women are at the level below men, so there are many things that women think are partly detrimental to women. As well as the case of women in the family or a clan fighting for power without thinking about existing customs.

Such is also represented in the novel Kenanga by Oka Rusmini. In the Kenanga novel, it is clear that women are always intimidated or restricted in doing something and must follow a rule or custom that exists in Bali. In this novel, Kenanga describes the case of groups in the family which is described clearly by the female character, Kenanga. Oka Rusmini seems to be the main character who wants to convey aspirations for women and represent to everyone that this is how women follow or have to enter into groups that have been determined by an area, and this is very detrimental to women especially because of the influence of their groups. especially in this study which will represent women in literary works written by authors of different genders and regions. This is conveyed by each author on his daily life as well as the addition of fiction in his work. 
Regarding literary works created by the author on what he sees and feels in his daily life, whether it is about social, cultural, political matters, in the family and society. In this study using a sociological study of literature. [3] suggests that in terms of sociology, society is closely related. with literature both in the family, environment, politics, economy and so on. Based on the things above, literary works are published in various forms. While novels are literary works that are different from others, such as short stories, poems, dramas and so on. A work in the form of a novel will make an author wider in conveying what he feels in written form. Many things are conveyed by the author in a work of educational, social, religious,

The conflicts that exist in the author's environment give rise to an idea for the author to present a literary work. In this case, it is described by female characters in particular. One of the authors who describes the representation of women in his work is in the form of novels entitled Negeri Perempuan by Wisran Hadi and Kenanga by Oka Rusmini. There are still many of their works that talk about women, especially Oka Rusmini who conveys a lot of women's desires and feelings in his work.

Then the sociology of literature is knowledge about the nature and development of society from or about the literature of critics and historians which mainly reveals the author who is influenced by the status of the strata of society where he comes from, political and social ideology.The literary work is considered a reflection or also a depiction of the real world, so the measure used is the extent to which the literary work is able to describe the actual object.

The clearer the literary work in describing the existing reality, the better the literary work. This type of criticism is very clearly influenced by the understanding of Aristotle and Plato, who stated that literature is an imitation of reality. Biography of each author and his work that describes the existing reality. Wisran Hadi, he was born and raised in the Minang realm, West Sumatra Province. He was born in Lapai, Padang on July 27, 1945 and died at the age of 66 years, June 28, 2011. Several awards he has won in 1991 and in 2000 the Writer award Best Indonesia by Culture and Education Ministry of the Republic of Indonesia. 2000 South East Asia (SEA) Write Award. In 2003 the Art Award from the Indonesian government.

He was even twice awarded by the Padang City Government (1976 and 2005) Exemplary Artist and Indonesian Cultural. From 2001 to 2005, he served as a lecturer in the History and Philosophy of Art and Creative Writing at the National Arts Academy (ASK) of the Malaysian Ministry of Arts and Heritage in Kuala Lumpur. Initially he was also an extraordinary lecturer at the Faculty of Letters, Andalas University, Padang. The author remains at several newspapers in West Sumatra. Apart from writing, he is also active in giving seminars both in Indonesia and outside Indonesia.

The works he has written and published are in the form of 50 drama scripts, 16 short stories, and several novels.
Novel entitled Tamu, publisher of PT Pustaka Utama Grafiti. Novel entitled Imam, publisher of Pustaka Firdaus, Jakarta. Novel entitled Orang Belanti, publisher of Cultural Image, Padang. Novel entitled Country of Women, publisher of Pustaka Firdaus Jakarta. Novel entitled Tanah Tepi, (the story of the journey of Hajj) publisher of Balai Pustaka Jakarta.

Short story entitled Daun-daun Mahogany Falls Again (a collection of 22 short stories) publisher Fajar Bakti. Short story entitled Three Heads, publisher Balai Pustaka Jakarta. The script for the drama, entitled Puti Bungsu Last Woman, was published by Pustaka Jaya and Balai Pustaka Jakarta. The manuscript, entitled Anggun Nan Tongga, is published by Balai Pustaka, Jakarta. Then the manuscript entitled Jalan Straight publisher PT Angkasa Bandung. A collection of manuscripts entitled Four Plays of the Malays, the publisher of PT Angkasa Bandung. Four Padri War plays in the form of a collection of manuscripts, publisher Angkasa Bandung. Spirit and Mrs. is also his manuscript that was published in the Drama Collection, publisher Grasindo Jakarta. Puppet field. and many of his other works.

However, the researcher chose one of his novels, entitled Negeri Perempuan because the researcher considered that the novel Negeri Perempuan had a lot of data on women's representation by studying sociology of literature, for example in the fourth title "Pucuk Adat" which discusses a lot about social relations in large families who take issue with women. which is honored, namely Bundo Kandung in its function in customs.

Wisran Hadi is also a leading writer in Indonesia who has regional characteristics. As well as efforts to revive the old Minang, Kabau and Malay traditions and myths in a contemporary form. He is also a writer who has different views on literary works, for example regarding the legend of Malin Kundang, according to him, Malin Kundang is not a rebellious child but a useful child.

Then why do researchers want to research this novel Negeri Perempuan as research material apart from the many problems of representation of women in this novel, in this novel there is also a clear foundation depicted from some of her works regarding the origin of society which will represent the regional women of Minag Kabau and all other things. such as cultural elements in aspects of life West Sumatraespecially. In this case, I will try to describe the representation of women from the point of view of sociological theorySatra that described in the novel Negeri Perempuan by Wisran Hadi.

In line with this, the comparison in research on women's representation is a novel by Oka Rusmini entitled Kenanga best it's the firs time on 2003, then reissued in 2017. One of the novels by Oka Rusmini that describes women is the ylang novel.His figures and works are impressed and often discussed because they raise issues of old or old Balinese customs and traditions and harm women, especially in the griya environment, the home of the Brahmins. 
This work of Oka Rusmini shows the condition of an area, namely Bali, as well as the variety of life that is thick with descriptions of customs and castes that have implications for social or cultural users. A brief overview of Oka Rusmini's biography. She is a female writer who was born in Bali. , on July 11, 1967. He has written many works in the form of novels, short stories and others. Apart from being a writer, he also works as a journalist and life style editor at the Bali Post daily. From some of his routine activities as a journalist and writer. This writing has become a supporting force for his career in producing many literary works. The events that he experienced in the environment had a role in the creation of Oka Rusmini's works.

Oka Rusmini's works are quite numerous, namely, a novel and Monologue Tree published in 1997. Earth dance, Shadow Country (1996), and the 21st Century Poet's Minbar. His short story, "Putu Menolong God", won the 1994 Femina Magazine Short Story Writing Competition. Oka Rusmini's writings are closely related to the culture of the Balinese people, specifically with the theme of the house family. This griya family is the residence of the Brahmins who are connected with various aspects, events, conflicts, customs, and the difficulties of Balinese life.

Oka Rusmini clearly shows the life of the house to the readers through her critical attitude which in this case causes a lot of harm to women. Oka Rusmini's writing is a manifestation of the representation of a Balinese woman. "Cultural and religious issues are women's issues, especially in Bali, and those who are allowed to speak about it are Balinese women themselves," said Oka Rusmini. This conveys that Oka Rusmini is a woman of Brahmin caste who has an influence on the image of the Kenanga character in the Kenanga novel. Oka Rusmini has been active in writing since she was a teenager, first writing in a diary. That's where his works started. The main factors in the life of Balinese people are culture and religion.

This novel focuses on the representation of women, namely Balinese women. Women in a family and society regarding their position become the main thing in this novel. If a woman obeys the customs and culture that has existed for a long time, then she is considered honorable. For any woman who violates these customs and culture, she will be excluded from the association of the community itself. The Kenanga character is a depiction of a woman who defends her life against her environment.

Based on the description above, research on women's representation representasi in the novel Negeri Perempuan by Wisran Hadi and the novel Kenanga by Oka Rusmini and the comparison of the two is important to find out information about the representation of a woman from the two novels in different regions and to show the differences in the representation of women's representation in the two novels in the sociological view of literature.

In this study, the author uses a sociological study of literature to analyze the novels of Negeri Perempuan by
Wisran Hadi and Kenaga by Oka Rusmini. The reasons behind the researcher choosing the novel entitled Negeri Perempuan dan Kenanga by Oka Rusmini are: First, this novel clearly describes the representation of women in the lives of the characters. Second, the author's point of view in addressing women's problems in customs and culture. The three novels both talk a lot about the representation of women in life which is conveyed through female characters. Fourth, Wisran Hadi is a prominent writer who has regional characteristics.

\section{METHOD}

The research method is basically a scientific way to get data with certain goals and uses [4]. [5] suggests that the research method is a method used in obtaining and collecting data from several informants. In this study the authors chose to use descriptive analysis method. The description of the analysis is carried out by describing the facts, then followed by describing to the stage of providing understanding and explanation (Ratna [6]).

In this case, the writer first describes the representation of women in the novel Negeri Perempuan by Wisran Hadi, and the Novel Kenanga by Oka Rusmini, then analyzes the contents of the novels.

\section{RESULTS AND DISCUSSION}

The research findings contain data, analysis, and interpretation of women's representation in the novels of Negeri Perempuan by Wisran Hadi and Kenanga by Oka Rusmini. From the research findings, the description of the lives of Minang women and the life of Balinese women are explained through narration and dialogue in the novel. The following is a description of the data, analysis, and interpretation of the research findings of the two novels.

\subsection{Data Novel Negeri Perempuan}

The girls who used to have long hair and came home from bathing from the beach with cloths that were sheathed up to their chests, now they wear jean pants, T-shirts without braids, loose hair without combs, colored lips and nails, (NP.8)

The data excerpt above illustrates the changing habits of a Minang woman who are influenced by foreign countries, as well as economic factors. Minang women who used to always maintain and cover their genitals are now gone because of the influence of these foreign countries.

At the same time, their new habits emerged, gambling in the bushes, drinking and getting drunk and then disturbing the visitors who came sometimes found them having sex in an empty place on the slopes or at the foot of Mount Patah Tujuh, without no one dares to prevent, (NP.8)

The description of the second data also strengthens the picture in data one, women even dare to 
do forbidden things such as gambling which is usually done by men, and it is seen that they are seductive women who dare to do indecent things such as adultery even in public places. and historic though. This data clearly describes Minang women who are still girls.

"If you want to make fun, don't bring my family!" said Reno sharply while hitting the table three times. (NP.9)

The data dialogue quote above illustrates that there are also women who are brave, ambitious. For the sake of defending the family, protecting and maintaining the good name. Usually they are not ordinary women but women who are respected or respected in their place of residence.

"Ten days ago three of them were brought by some youths who came from nowhere. Just got home two days later. When asked, without the slightest sense of guilt they even proudly said they were staying at the Nagariten. The three girls are indeed famous gata (naughty)! We will be even more embarrassed if they become such a (wild) woman," he continued. (NP.12)

In the data excerpt above, it describes women whose self-esteem can be bought, even if they do not have self-respect anymore and make their own country ashamed, even though it is known by many people that they do not have the slightest fear or shyness.

"Now it's our girls' turn that men carry everywhere! Tomorrow or the day after tomorrow, their mothers may also be traded for their children," said Bundo, full of doubts. (NP.12)

In the quote above, it is described that there is a woman whose responsibility is in a country or region in the Minag area called Bundo Kanduang, she is angry, annoyed and gives advice, thinks about the behavior of girls and maintains the good name of her area. That is the figure of a woman who is respected and respected in the Minang realm. Bundo Kanduang is where they complain and tell stories and ask for or give advice.

\subsection{Data Novel Kenanga}

In fact, at that time he only had Memories. A girl. Meanwhile, as usual for the noble houses of the house, his parents wanted a son. Automatically lost hope. (K.17)

In the data excerpt above, it is clearly described that a girl born into a noble family does not have the hope of becoming an important part or getting a position in the family, because the son has the right.

Uncle Rahyuda is married to a beautiful woman who is twenty years his junior. The woman was a sudra who was handed over by her parents because her parents asked her to do so. (K.20)

In the data excerpt above, it is clear that women were born from the class of ordinary people or commoners, and they also accept what is, as illustrated from a very far age gap.

The woman's real name is actually Luh Putu Arimbi. Since being married to Rahyuda's uncle who is a Brahmin caste, according to tradition his name was changed and he was given the title "Jero". (K.22)

In the data excerpt above, it is described as a woman who is in a low class or commoner, and married a man from the nobility and she also got a title because she followed her husband, but in essence she was just an ordinary woman who could not do anything. often even bullied.

Marriage also obliges him to leave his family, ancestors, customs, relatives and even his own body, all of which are part of the past. An initiation ceremony has been held to break the chain of his personal history. Once a woman gets the status of a wife, let alone a brahmin's wife, socially and cosmically she is a new woman belonging to her husband's family. (K.22)

In the excerpt of the data above, it is clearly described how women who are born into the common people group, if married to a noble person in this case the bramana group. They are obliged to cut off all relations with family, friends, including customary matters even among the common people.

Just look at the marriage between Mr. Antara and Mrs. Susila. At first they were so enthusiastic about breaking through customs to get to the marriage ceremony. Mrs. Susila was willing to be expelled from the castle because she was dragging her feet, marrying off caste. (K.24)

In the quote above, it is clearly described about women in several groups or castes, and they too, women in Bali have groups and their groups if she is in the position of a woman if she wants to marry a different caste.

Based on the findings of research on women's representation in the novel Negeri Perempuan by Wisran Hadi and Kenanga by Oka Rusmini, this will discuss how the description of a woman in Minang Kabau and Balinese women who are in a clan or institution, and family, is conveyed by the author in the work. his fiction and added to the daily reality that is 
seen and experienced by the author must no longer be in accordance with the current reality. In the novel Negeri Perempuan, Women in Minang Kabau are highly respected and admired. Also depicted is the character of the female character who is idealistic, brave, patient, compassionate.

Bundo kanduang literally means a call for a mother. However, in the general point of view in Minang Kabau bundo kanduang is a female heir to the kingdom like Bundo kanduang which is the nickname of a woman who leads a family in Minang Kabau both as queen and as mother of the king. Although in the kinship or family structure the position of women is quite strong, in the wider social structure their position is not like that, because men represent the interests of the family in dealings with outsiders. This means that women are still limited in their role in society, even though from reality it is found that many women have careers because of their education. In this novel, many things are depicted in women, both as children, sisters and so on in matters of family and social society related to cultural customs because basically Bundo Kanduang is a person who plays a very important role in maintaining customs and culture in his country. However, this is what is depicted today that women are fighting for power, and power has made a person forget about customs and culture. Then women who uphold culture and struggle against existing influences which are clearly described by the main character in this novel, namely Reno, as well as women who have been affected and are far from the attention of their families who have fallen into negative things.

Then the Balinese woman described in the novel Kenanga by Oka Rusmini is a woman who is brave, ambitious, idealistic, and patient, this is described through her main character, Kenanga. Because in the family's view they are in the Brahmins while the other women come from ordinary people, in a social interaction, they are very different because of their caste, or position, so that it is clearly illustrated how women and a family and women in society are. Society is the people or groups of people who are in an area. The author describes how the role of women according to their caste or clan, such as women who are weak due to group or heredity factors. Because in Bali this is patriarchal lineage from the father.

After that, Balinese women also could not do anything in pursuing a career, especially among the common people and there was also a lot of treatment that they did not deserve because of their class, or roughly oppression by men in respectable groups. However, it is also clear that the role of women who have positions or are in the Brahmin group who cares and thinks about and fights for women in social relations to society must have this patriarchal culture already embedded in Balinese society, and this can also be seen from a sociological point of view.

Then the difference between each author in describing women in his works is different. Wisran Hadi with his novel entitled Country of women, he describes a woman who is essentially a special person, admired and respected, and women who hold positions such as Bundo Kanduang have an important role to maintain the culture in their country in various ways such as inheritance, choosing partners who are not allowed to belong to one group or people, especially women, as well as how their role in social society, apart from custom, is also influenced by belief or religion factors. So that in Minang Kabau was born an advice "adat basandi sarak, sarak basandi kitaullah" which means culture is closely related to religion or the Koran.

Meanwhile, Balinese women are described by Oka Rusmini in his work, society is bound by culture and class, in this case many are detrimental to women. For example, getting oppressed, especially women, commoners. Because in Bali there are castes or groups for the people. In Bali, there is a patriarchal or patriarchal lineage so that men are more respected, especially if they are in the Brahmin group. In this case, they feel they can do whatever they want and are also strengthened by the existing culture, that men who are in the Brahmin class can choose and treat women from the common people as they wish.

So in this case, it is seen that women who have an attitude or character are ambitious, brave, apathetic, patient and so on because the things they experience are detrimental to their community and must follow existing traditions or culture even though this is contrary to their expectations. This is the case of women depicted by Oka Rusmini in family and society in her work.

\section{CONCLUSION}

The results of research and discussion on the representation of women in the family and society in the novel Negeri Perempuan by Wisran Hadi and Kenanga by Oka Rusmini, can be concluded as follows. In analyzing the representation of women in the family and society in the novel Negeri Perempuan by Wisran Hadi, it was found that there were 48 women's representation data in the family, 20 women's representation data in society. The data found in the novel Negeri Perempuan very much describe a woman in terms of their role in an institution or family, their position in the family and institutional conflicts in the family and their role in society.

The representation of women in the family and society in Kenanga Oka Rusmini's novel found 28 data on representation of women in the family, 17 data on representation of women in society. The data found in the novel Kenanga very much describe a woman in terms of caste or class, and her obligation to follow existing customs, as well as regarding marriage or matchmaking which is very detrimental to women because of the caste factor.

In general, what is described in these two novels, the novel Negeri Perempuan dan Kenanga describes the role of women in the family and society related to customs or culture that harm women a lot, as well as women who 
have power because of their caste or group in a family or society. to act or do. The representation of women is described in the analysis and discussion of the data with the study of sociology of literature, which totals 113 data.

\section{REFERENCES}

[1] Zulkarnaini, 2008. Learning Indonesian Language and Literature. id. Wordpress.com

[2] Rusyana, 1982. Literary Learning Methods. Bandung. Forbidden Mountain.

[3] Damono, Sapardi Djoko. 1978. Sociology of Literature, A Brief Introduction. Jakarta. Department of Education and Culture.

[4] Sugiyono, 2012. Qualitative Research Methods and R\&D. Bandung. Alphabet.

[5] Arikunto, S. 2006. Qualitative Research Methods. Jakarta: Earth Literacy.

[6] Ratna, Nyoman Kutha. 2003. The Sociology of Literature Pradigma. Yogyakarta: Pustaka Pelajar 